\title{
Extraction of Natural Dye from Ficus cunia and Dyeing of Polyester Cotton and Wool Fabric Using Different Mordants, with Evaluation of Colour Fastness Properties
}

\section{Jyoti Kundal ${ }^{1 *}$, Shyam Vir Singh² and Purohit MC}

${ }^{1}$ Department of Chemistry, HNB Garhwal University (A Central University), Campus Pauri (Garhwal), Uttarakhand-246 001, India ${ }^{2}$ Department of Chemistry, SGRR PG College, Pathri Bagh, Dehradun, Uttarakhand-248 001, India

\begin{abstract}
Due to the various side-effects of synthetic dye, a need has been felt to discover the new dye yielding plants and optimization of various conditions of dyeing. Ficus cunia was proved to be the good dye yielding plant and wide range of color shades were obtained when different mordants were used with different mordanting methods. Leaves of this plant were used for dyeing wool and polyester cotton (PEC) using different mordants, viz. Potassium Aluminium Sulphate, Ferrous Sulphate, Stannous Chloride and Tannic Acid along with one natural mordant. The natural dye extract gave different shades using different natural and synthetic mordants. The washing, rubbing and light fastness properties of dyed samples were assessed and good to excellent fastness grades were obtained.
\end{abstract}

Keywords: Ficus cunia; Mordants; Natural dye; K/S value; Wool and polyester cotton

\section{Introduction}

The genus Ficus belongs to family Moraceae. This genus includes about 750 species of woody plants [1]. It is evergreen tree up to $5 \mathrm{~m}$ tall. Bark- rough, dark-grey, leaves- lamina variable, mostly elliptical base highly unequal sided. The water extract of bark of this plant is used for bath to fight leprosy and juice from root is administrated for liver problems [2]. Dyeing with natural resources is an oldest technique, even today in most of the regions, despite the availability of synthetic dyes, many people continue to use plant extracts for color fabrics, masks or food. Various researches have shown that some dyes from plants generally possess desirable colour properties and good performance on natural fibres which are comparable to some highly rated synthetic dye [3-5].

Natural dyes have also better biodegradability and generally have higher compatibility with the environment. They are nontoxic, nonallergic to skin, non-carcinogenic, easily available and renewable [6,7]. The invention of the first synthetic dyes by William Henry Perkin in 1856 changed the situation and later, the synthetic dyes received faster acceptability due to a wide range of applications in various fields like food [8] cosmetic [9] photodynamic therapy [10] non-linear optical activity [11] and more importantly in textile industries due to ease in dyeing, and overall cost factor $[12,13]$. But, during the last few decades, the use of synthetic dyes is gradually decreasing due to an increased environmental awareness and harmful effects because of either toxicity or their non-biodegradable nature.

As a result, recently a ban has been imposed all over the world including European Economic Community (EEC), Germany, USA and India on the use of some synthetic dyes. The advantages of using natural colorants are manifolds as they are eco-friendly, safe for body contact, unsophisticated and harmonized with nature [14] obtained from renewable sources and also their preparation involves a minimum possibility of chemical reactions. The shades produced by natural dyes/colorants are usually soft, lustrous and soothing to the human eye. However, the natural dyes have their own limitations like availability, color yield, stability, and complexity of dyeing process and reproduction of shades but these problems can overcome by using synthetic mordants.

Present study deals with the dyeing of polyester cotton and wool with the leaves of Ficus cunia, efforts has also been done to optimize the best mordanting method and shades obtained using various mordants.

\section{Materials and Methods}

\section{Collection of plant material}

Leaves of Ficus cunia were collected from Pauri district of Uttarakhand, then dried and crushed in a fine powder. This powdered leaves were used as a dye material (Figure 1).

\section{Extraction of dye for wool and PEC}

Aqueous dye solution was prepared, by adding 5 gm of leaves of Ficus cunia in $100 \mathrm{ml}$ of water. The extraction was done at $100^{\circ} \mathrm{C}$ for

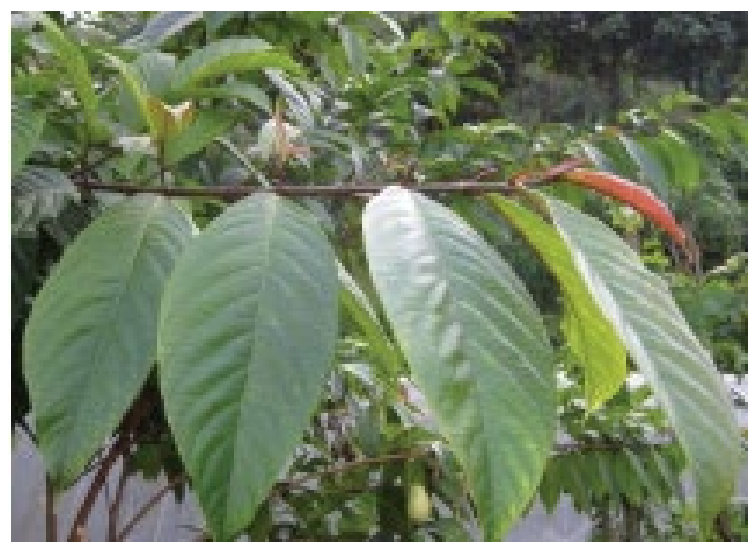

Figure 1: Leaves of Plant Ficus cunia.

*Corresponding author: Jyoti Kundal, Department of Chemistry, HNB Garhwal University (A Central University), Campus Pauri (Garhwal), Uttarakhand-246 001, India, E-mail: jkundal2000@yahoo.com

Received March 14, 2016; Accepted March 21, 2016; Published March 29, 2016

Citation: Kundal J, Singh SV, Purohit MC (2016) Extraction of Natural Dye from Ficus cunia and Dyeing of Polyester Cotton and Wool Fabric Using Different Mordants, with Evaluation of Colour Fastness Properties. Nat Prod Chem Res 4 214. doi:10.4172/2329-6836.1000214

Copyright: $\odot 2016$ Kundal J, et al. This is an open-access article distributed under the terms of the Creative Commons Attribution License, which permits unrestricted use, distribution, and reproduction in any medium, provided the original author and source are credited. 
Citation: Kundal J, Singh SV, Purohit MC (2016) Extraction of Natural Dye from Ficus cunia and Dyeing of Polyester Cotton and Wool Fabric Using Different Mordants, with Evaluation of Colour Fastness Properties. Nat Prod Chem Res 4: 214. doi:10.4172/2329-6836.1000214

one hour at 6-7 $\mathrm{pH}$. The hot solution was filtered and a clear solution was obtained which is used for dyeing wool fabric. Same extraction was done for Polyester cotton at 8-9 $\mathrm{pH}$.

\section{Mordants used}

Three synthetic mordants and one natural mordant were used for mordanting viz. Potassium Aluminium sulphate, Stannous Chloride, Ferrous sulphate and Tannic acid.

\section{Mordanting methods used}

Pre-mordanting: Fabric was treated with mordant for 30 minute at $60^{\circ} \mathrm{C}$, wool and polyester cotton was dyed by the standard method prescribed for natural dyes. The dyeing was carried out at 1:30 MLR (material to liquor ratio), for $40 \mathrm{~min}$ at $80^{\circ} \mathrm{C}$. Dyeing and mordanting is done by using Rota-Dyeing machine. As we know that synthetic mordants are very toxic and their maximum use can create an environmental issue so only $1 \%$ of mordanting was done which is a permissible limit.

Post-mordanting: In this method both the fabric were dyed first then mordanting as the method used above and rinsed in hot and then cold water and finally treated with mordant solution for 30 minute at $60^{\circ} \mathrm{C}$ and rinsed.

Simultaneous-mordanting: $1 \mathrm{ml}$ of $1 \%$ mordant is mixed with 30 $\mathrm{ml}$ of dye extract and then $1 \mathrm{gm}$ of fabric is dyed with it for 40 minutes at $60^{\circ} \mathrm{C}$.

Different fastness properties: Dyed fabrics were then undergone different fastness tests viz. light, washing and rubbing etc. to optimize the best shade and best method of dyeing.

\section{Test for color fastness to light}

This test is carried out as per IS: 2454-1984 method. The dyed samples of $3 \times 6 \mathrm{~cm}$ were fixed on a black cardboard in such a way that all samples were half exposed and half covered. This frame was placed inside the fadeometer fitted with mercury bulb tungsten lamp (MBTF). The specimens were brought out after 17 hour and color fading was assessed against the blue wool standards (BS 1006: BOI: 1978).

\section{Test for color fastness to washing using Launderometer (TC/ UICT/TEQIP)}

Color fastnesses to washing of the dyed samples were determined as per IS: 764-1984 method. In this test the different dyed fabric were cut into pieces of $10 \times 4 \mathrm{~cm}$ and placed between two pieces of undyed fabrics (wool and cotton) of same size all three layers were sewn from all side this is said to be the sandwich type of arrangement of fabrics. The washing is done by $5 \%$ non-ionic soap solution (cell det (R)) for 60 minute using Washing fastness tester (Laundarometer) using 50 steel balls. The samples were rinsed in running water and dried in shade and then assessed with the help of grey scale (ISO: 05-A02) and (ISO105-A02) for loss of shade and extent of staining.

\section{Test for color fastness to rubbing}

This test was done as per IS: 766-1984 method using Crock meter. A piece of cotton was rubbed 10 times on a sample with the help of crock meter. Two types of rubbing were done, wet rubbing and dry rubbing. The staining on the wet and dry piece of fabric is evaluated with the help of grey scale as per ISO-105-A03.

\section{$\mathrm{K} / \mathrm{S}$ values (Determination of surface color strength) (Dye ability of dyed fabric)}

The K/S value of the dyed and undyed wool and cotton fabrics was determined by measuring surface reflectance of the sample using a computer aided Mcbeth 2020 plus reflectance spectrophotometer using the following Kubelka-Munk equation

$$
\frac{\mathrm{K}}{\mathrm{S}}=\frac{\left(1-\mathrm{R}_{\lambda \max }\right)^{2}}{2 \mathrm{R}_{\lambda \max }}
$$

Where $\mathrm{K}$ is the coefficient of absorption, $\mathrm{S}$ is the coefficient of

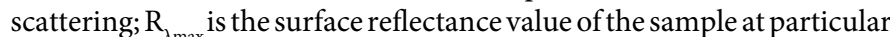
wavelength when maximum absorption occurs for a particular dye / colorant. The $\mathrm{K} / \mathrm{S}$ values of dyed yarn is directly proportional to the amount of dye present in the material and it has been also found that generally $\mathrm{K} / \mathrm{S}$ value get increase with mordants.

\section{Results and Discussion}

The preliminary experiments shows that the leaves of Ficus cunia yield a wide range of colors and so detail study was conducted to standardize the methods of extraction and application of dyes on polyester cotton (PEC) and wool yarn. The results obtained are discussed below.

\section{Fastness tests}

Color fastness to washing: The samples were assessed on the basis of change in color and staining on the adjacent fabrics with the help of grey scale. The rating is given in Table 1 on the basis of which, it has been found that in PEC, good to excellent (4 to 4-5) fastness grading

\begin{tabular}{|c|c|c|c|c|c|c|c|c|}
\hline \multirow[t]{2}{*}{ S No } & \multirow[t]{2}{*}{ Mordant used } & \multirow[t]{2}{*}{$\begin{array}{l}\text { Mordanting } \\
\text { Method }\end{array}$} & \multirow[t]{2}{*}{$\begin{array}{l}\text { Color change } \\
\text { (PEC) }\end{array}$} & \multirow[t]{2}{*}{$\begin{array}{l}\text { Color change } \\
\text { (Wool) }\end{array}$} & \multicolumn{2}{|c|}{$\begin{array}{l}\text { Staining } \\
\text { (PEC) }\end{array}$} & \multicolumn{2}{|c|}{$\begin{array}{c}\text { Staining } \\
\text { (Wool) }\end{array}$} \\
\hline & & & & & Cotton & PEC & Cotton & Wool \\
\hline \multirow[t]{3}{*}{1.} & \multirow[t]{3}{*}{ Pot. Alum. sulphate } & Pre & $4 / 5$ & 4 & $4 / 5$ & $4 / 5$ & $4 / 5$ & 4 \\
\hline & & Post & $4 / 5$ & 4 & $4 / 5$ & 4 & 5 & 5 \\
\hline & & Sim. & 4 & $4 / 5$ & $4 / 5$ & $4 / 5$ & $4 / 5$ & $4 / 5$ \\
\hline \multirow[t]{3}{*}{2.} & \multirow[t]{3}{*}{ Tannic acid } & Pre & $4 / 5$ & 2 & $4 / 5$ & 4 & $4 / 5$ & $4 / 5$ \\
\hline & & Post & $4 / 5$ & $4 / 5$ & $4 / 5$ & $4 / 5$ & 5 & $4 / 5$ \\
\hline & & Sim. & 4 & $3 / 4$ & $4 / 5$ & 4 & $4 / 5$ & $4 / 5$ \\
\hline \multirow[t]{3}{*}{3.} & \multirow[t]{3}{*}{ Ferrous sulphate } & Pre & $4 / 5$ & $2 / 3$ & $4 / 5$ & $4 / 5$ & $4 / 5$ & $4 / 5$ \\
\hline & & Post & $4 / 5$ & 5 & $4 / 5$ & 4 & $4 / 5$ & $4 / 5$ \\
\hline & & Sim. & 4 & $1 / 2$ & $4 / 5$ & 45 & $4 / 5$ & 4 \\
\hline \multirow[t]{3}{*}{4.} & \multirow[t]{3}{*}{ Stannous chloride } & Pre & 5 & 3 & $4 / 5$ & $4 / 5$ & $4 / 5$ & $4 / 5$ \\
\hline & & Post & $4 / 5$ & $4 / 5$ & $4 / 5$ & $4 / 5$ & 5 & $4 / 5$ \\
\hline & & Sim. & 4 & $4 / 5$ & $3 / 4$ & $4 / 5$ & $4 / 5$ & 5 \\
\hline
\end{tabular}

Table 1: Rating of Fastness to washing for PEC and Wool. 
Citation: Kundal J, Singh SV, Purohit MC (2016) Extraction of Natural Dye from Ficus cunia and Dyeing of Polyester Cotton and Wool Fabric Using Different Mordants, with Evaluation of Colour Fastness Properties. Nat Prod Chem Res 4: 214. doi:10.4172/2329-6836.1000214

ranges were obtained with four mordants. In case of wool, fastness grading ranges good to very good (4 to 5) were obtained with Pot. Alum. Sulphate mordant, poor to very good (2 to 4$)$ with Tannic acid, poor to excellent (1/2 to 5) with $\mathrm{FeSO}_{4}$ and fair to very good (3 to $\left.4 / 5\right)$ with Stannous chloride were obtained (Table 2).

Color fastness to rubbing: Color Fastness to rubbing used to determine the stability of the dyed color on the Fabrics. The values obtained for PEC, shows that there was no color staining to excellent (4/5 to 5) with Tannic acid and $\mathrm{FeSO}_{4}$, whereas no color staining (5) with Potassium aluminium sulphate and stannous chloride were obtained in case of dry rubbing. In case of wet rubbing a noticeable to slight (3 to 4) staining with $\mathrm{SnCl}_{2}$ and Potassium aluminium sulphate, a noticeable to negligible (4 to $4 / 5)$ with $\mathrm{FeSO}_{4}$, slight to negligible (4 to $4 / 5$ ) with Tannic acid were obtained. In case of dry rubbing slight to non-staining (4 to 5) range of fastness was obtained using four mordants for wool fabric. In case of wet rubbing noticeable to negligible (3/4 to 4/5) staining range were obtained with all the four mordants.

Color fastness to light: Light is also a very important factor which effects the color, generally color get faded in sun light so this test gives very important information that whether the color applied on fabric is stable to light or not. So to perform this test dyed samples were placed in light for more than 15 hour continuously. Table 3, indicates that for PEC, dyeing along with Potassium aluminium sulphate, Tannic acid and $\mathrm{SnCl}_{2}$ gave the good to very good (5 to 6) fastness grade and good to excellent (5 to 7) with $\mathrm{FeSO}_{4}$. For wool dyeing along with Tannic acid and $\mathrm{FeSO}_{4}$ showed very good to excellent (6 to 7) fastness grading whereas very good (6) for Potassium aluminium sulphate and good to very good (5 to 6) for $\mathrm{SnCl}_{2}$ were obtained.

\begin{tabular}{|c|c|c|c|c|}
\hline S No & Mordant used & $\begin{array}{l}\text { Mordanting } \\
\text { Method }\end{array}$ & $\begin{array}{c}\text { Rating } \\
\text { Values } \\
\text { (PEC) }\end{array}$ & $\begin{array}{l}\text { Rating values } \\
\text { (Wool) }\end{array}$ \\
\hline \multirow{3}{*}{1.} & \multirow{3}{*}{ Pot. Alum. Sulphate } & Pre & 5 & 6 \\
\hline & & Post & $5 / 6$ & 6 \\
\hline & & Sim. & 6 & 6 \\
\hline \multirow{3}{*}{2.} & \multirow{3}{*}{ Tannic acid } & Pre & 6 & 6 \\
\hline & & Post & 6 & 7 \\
\hline & & Sim. & 5 & 6 \\
\hline \multirow{3}{*}{3.} & \multirow{3}{*}{ Ferrous sulphate } & Pre & 5 & 7 \\
\hline & & Post & 7 & 7 \\
\hline & & Sim. & 6 & 6 \\
\hline \multirow{3}{*}{4.} & \multirow{3}{*}{ Stannous chloride } & Pre & 5 & 5 \\
\hline & & Post & 6 & 6 \\
\hline & & Sim. & 5 & 6 \\
\hline
\end{tabular}

Table 2: Rating of Fastness to Rubbing for PEC and Wool.

\begin{tabular}{|c|c|c|c|c|c|c|}
\hline \multirow[t]{2}{*}{ S No } & \multirow[t]{2}{*}{ Mordant used } & \multirow[t]{2}{*}{$\begin{array}{l}\text { Mordanting } \\
\text { Method }\end{array}$} & \multicolumn{2}{|c|}{$\begin{array}{l}\text { Staining } \\
\text { (PEC) }\end{array}$} & \multicolumn{2}{|c|}{$\begin{array}{c}\text { Staining } \\
\text { (Wool) }\end{array}$} \\
\hline & & & Dry & Wet & Dry & Wet \\
\hline \multirow[t]{3}{*}{1.} & \multirow[t]{3}{*}{ Pot. Alum. sulphate } & Pre & 5 & 3 & 4 & 4 \\
\hline & & Post & 5 & 4 & 4 & 4 \\
\hline & & Sim. & 5 & 4 & $4 / 5$ & $3 / 4$ \\
\hline \multirow[t]{3}{*}{2.} & \multirow[t]{3}{*}{ Tannic acid } & Pre & 5 & $4 / 5$ & $4 / 5$ & $4 / 5$ \\
\hline & & Post & 5 & 4 & $4 / 5$ & $4 / 5$ \\
\hline & & Sim. & $4 / 5$ & 4 & $4 / 5$ & $3 / 4$ \\
\hline \multirow[t]{3}{*}{3.} & \multirow[t]{3}{*}{ Ferrous sulphate } & Pre & 5 & 4 & 4 & $3 / 4$ \\
\hline & & Post & $4 / 5$ & 3 & $4 / 5$ & 4 \\
\hline & & Sim. & 5 & $4 / 5$ & 5 & 4 \\
\hline \multirow[t]{3}{*}{4.} & \multirow[t]{3}{*}{ Stannous chloride } & Pre & 5 & 4 & 4 & $3 / 4$ \\
\hline & & Post & 5 & 4 & $4 / 5$ & 4 \\
\hline & & Sim. & 5 & 3 & $4 / 5$ & $3 / 4$ \\
\hline
\end{tabular}

Table 3: Rating of Fastness to Light for PEC and Wool.
Dye ability test (K/S values): The color strength of dyed fabric was assessed by using computer color matching machine, $\mathrm{k} / \mathrm{s}$ values of all the dyed samples were determined (Table 4). According to values it is clear that wool sample absorb the more natural colorant as compare to PEC. In case of wool maximum color strength was shown by mordant $\mathrm{FeSO}_{4}$ than after Potassium aluminium sulphate and $\mathrm{SnCl}_{3}$, color absorption with Tannic acid was very less and its effect can be seen in Photograph 2. For PEC absorption 9 was very less and again $\mathrm{FeSO}_{4}$ gave the maximum absorption.

Color shades obtained: An original Camelion brown color was obtained with the leaves of Ficus cunia on both PEC and Wool fabrics, when it was treated with the different mordant and mordanting methods, a large no of shades were obtained (Table 5) as given below and effects can be seen in Photographs 1-8.

\section{Conclusion}

Ficus cunia locally known as Khaina is so far chemically unexplored in terms of dye properties, can be proved to be the dye yielding plant of Garhwal Himalaya. The leaves of this plant gave wide range of color/ shades using different synthetic and natural mordants with different mordanting methods. The colorant produced from the leaves of this plant is also found to be very stable on fibres; it is further supported by the different fastness test. The present work is the little bit effort

\begin{tabular}{|c|c|c|c|c|}
\hline S No & Mordant used & $\begin{array}{l}\text { Mordanting } \\
\text { Method }\end{array}$ & $\begin{array}{c}\text { K/S Values } \\
\text { (Wool) }\end{array}$ & $\begin{array}{l}\text { K/S Values } \\
\text { (PEC) }\end{array}$ \\
\hline \multirow[t]{3}{*}{1.} & \multirow{3}{*}{ Pot. Alum. Sulphate } & Pre & 5.8607 & 0.9004 \\
\hline & & Post & 3.546 & 1.7169 \\
\hline & & Sim. & 2.4993 & 1.4429 \\
\hline \multirow[t]{3}{*}{2.} & \multirow{3}{*}{ Tannic acid } & Pre & 2.7648 & 0.8123 \\
\hline & & Post & 2.8134 & 1.3366 \\
\hline & & Sim. & 2.2079 & 1.4528 \\
\hline \multirow[t]{3}{*}{3.} & \multirow{3}{*}{ Ferrous sulphate } & Pre & 9.0913 & 0.3638 \\
\hline & & Post & 6.5487 & 2.2018 \\
\hline & & Sim. & 2.2358 & 2.2310 \\
\hline \multirow[t]{3}{*}{4.} & \multirow{3}{*}{ Stannous chloride } & Pre & 4.3455 & 1.3884 \\
\hline & & Post & 2.7463 & 0.6138 \\
\hline & & Sim. & 3.8634 & 1.1025 \\
\hline
\end{tabular}

Table 4: K/S Values of Wool and PEC samples dyed by plant Ficus cunia.

\begin{tabular}{|c|c|c|c|c|}
\hline S No & Mordant used & $\begin{array}{l}\text { Mordanting } \\
\text { Method }\end{array}$ & (PEC) & (Wool) \\
\hline \multirow{3}{*}{1.} & \multirow{3}{*}{$\begin{array}{l}\text { Pot. Alum. } \\
\text { Sulphate }\end{array}$} & Pre & Pinkish brown & Dark yellowish \\
\hline & & Post & Dark camelion & Yellowish brown \\
\hline & & Sim. & Light camelion & $\begin{array}{c}\text { Light brownish } \\
\text { yellow }\end{array}$ \\
\hline \multirow{3}{*}{2.} & \multirow{3}{*}{ Tannic acid } & Pre & Dark camelion & Yellowish brown \\
\hline & & Post & $\begin{array}{l}\text { Light brown } \\
\text { pinkish }\end{array}$ & Yellowish brown \\
\hline & & Sim. & Pinkish brown & $\begin{array}{l}\text { Light Yellowish } \\
\text { brown }\end{array}$ \\
\hline \multirow{3}{*}{3.} & \multirow{3}{*}{$\begin{array}{l}\text { Ferrous } \\
\text { sulphate }\end{array}$} & Pre & Blackish brown & Pinkish dark grey \\
\hline & & Post & Dark grey & Dark grey \\
\hline & & Sim. & Creamish white & Light grey \\
\hline \multirow{3}{*}{4.} & \multirow{3}{*}{$\begin{array}{l}\text { Stannous } \\
\text { chloride }\end{array}$} & Pre & Pinkish brown & Yellowish brown \\
\hline & & Post & Light brown & Light brown \\
\hline & & Sim. & Pinkish brown & Dark brown \\
\hline
\end{tabular}

PEC: Polyester cotton; Sim: Simultaneous

Table 5: Showing the various shades obtained from different mordants and mordanting methods. 
Citation: Kundal J, Singh SV, Purohit MC (2016) Extraction of Natural Dye from Ficus cunia and Dyeing of Polyester Cotton and Wool Fabric Using Different Mordants, with Evaluation of Colour Fastness Properties. Nat Prod Chem Res 4: 214. doi:10.4172/2329-6836.1000214

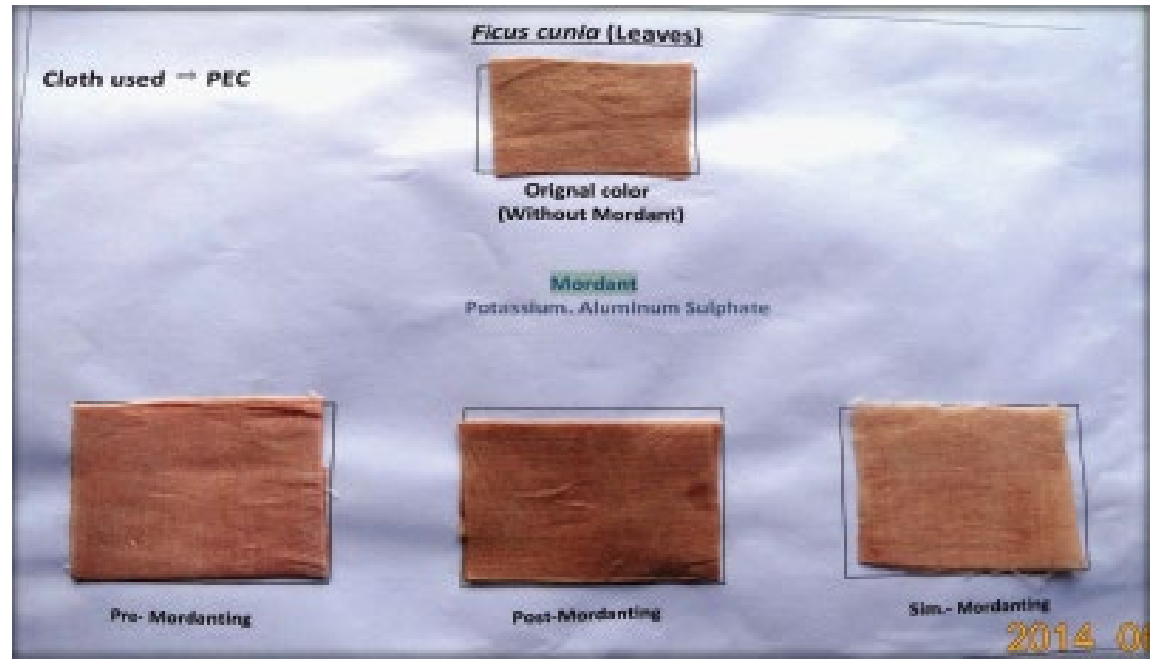

Photograph 1: Shows effects of various shades obtained from different mordants and mordanting methods.

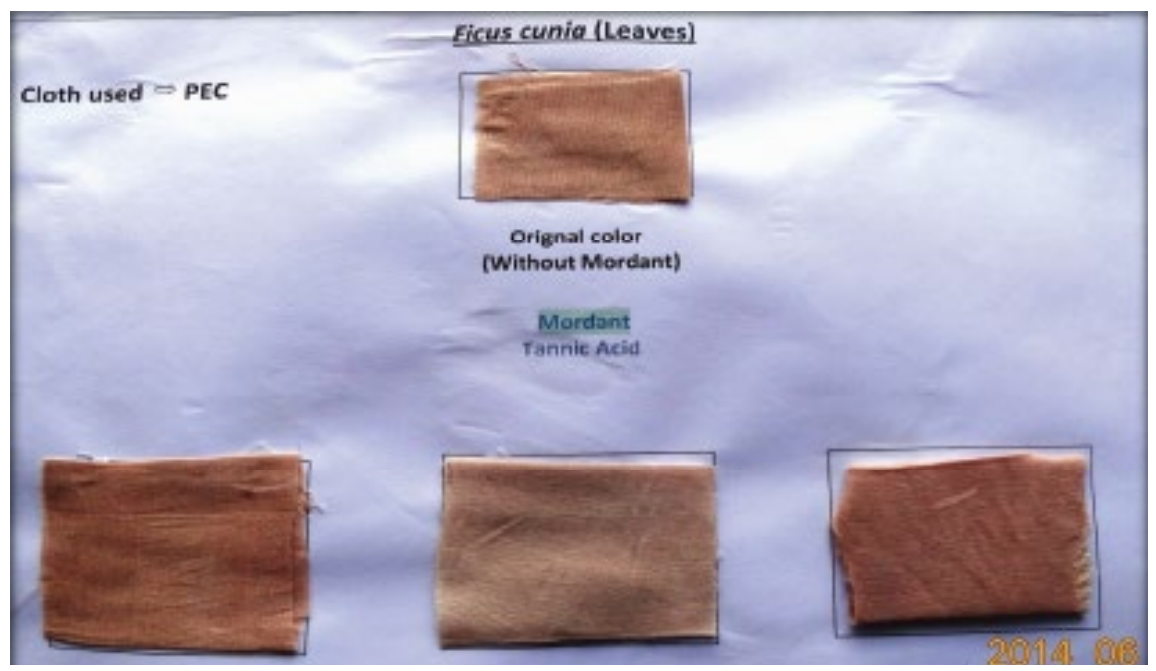

Photograph 2: Shows effects of various shades obtained from different mordants and mordanting methods.

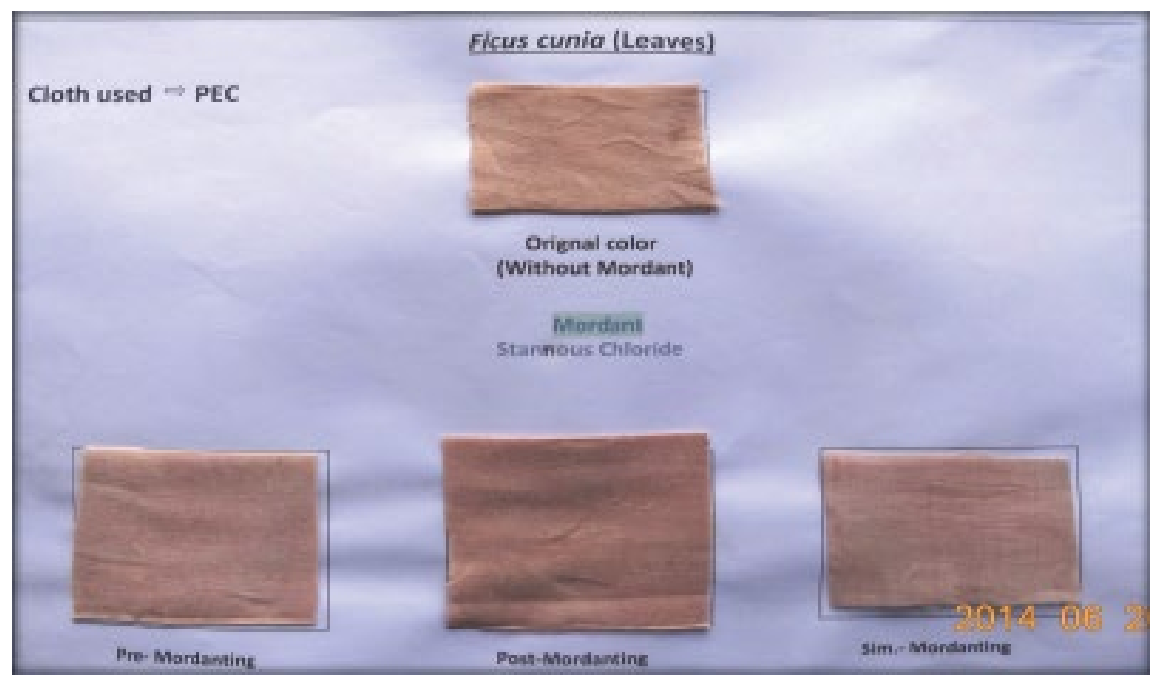

Photograph 3: Shows effects of various shades obtained from different mordants and mordanting methods. 


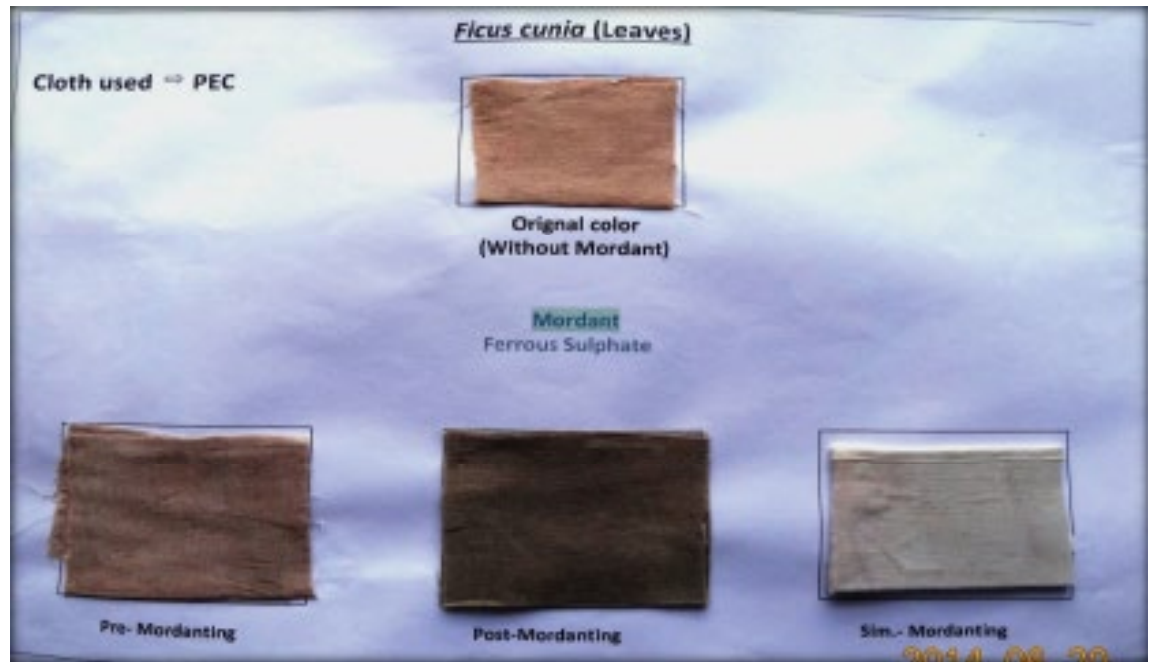

Photograph 4: Shows effects of various shades obtained from different mordants and mordanting methods.

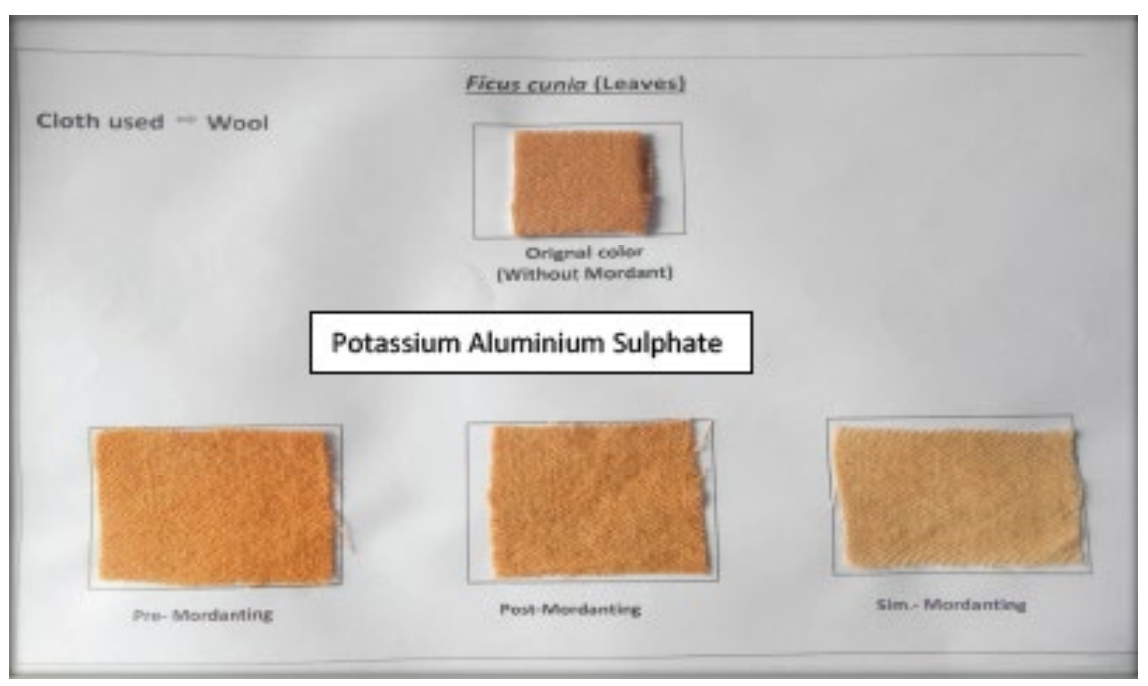

Photograph 5: Shows effects of various shades obtained from different mordants and mordanting methods.

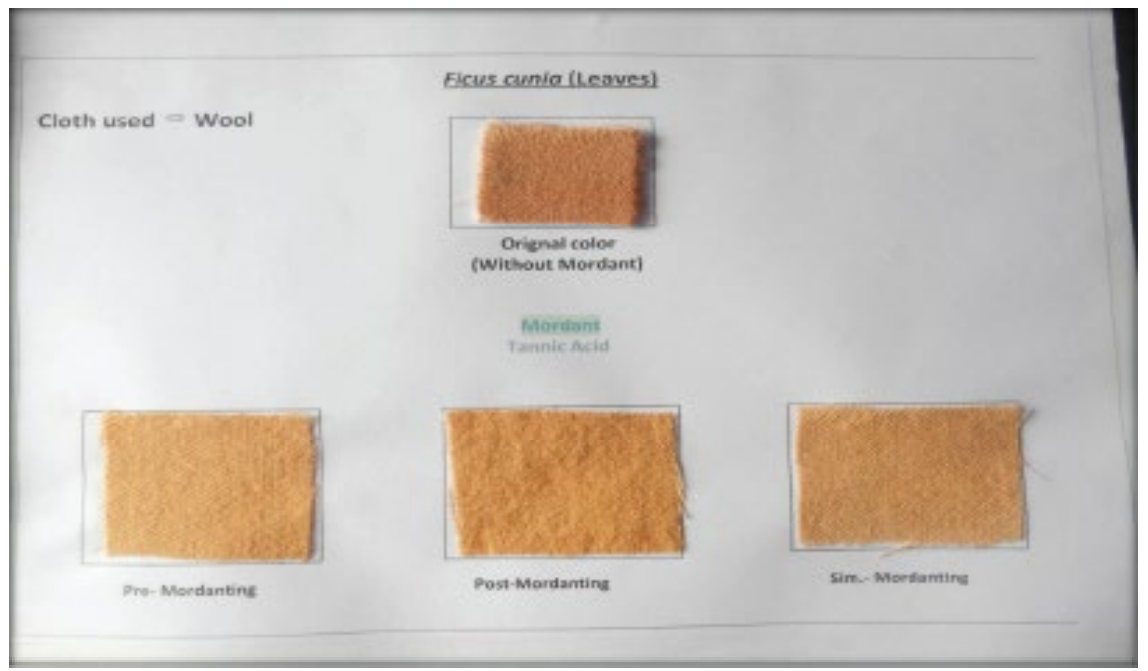

Photograph 6: Shows effects of various shades obtained from different mordants and mordanting methods. 
Citation: Kundal J, Singh SV, Purohit MC (2016) Extraction of Natural Dye from Ficus cunia and Dyeing of Polyester Cotton and Wool Fabric Using Different Mordants, with Evaluation of Colour Fastness Properties. Nat Prod Chem Res 4: 214. doi:10.4172/2329-6836.1000214

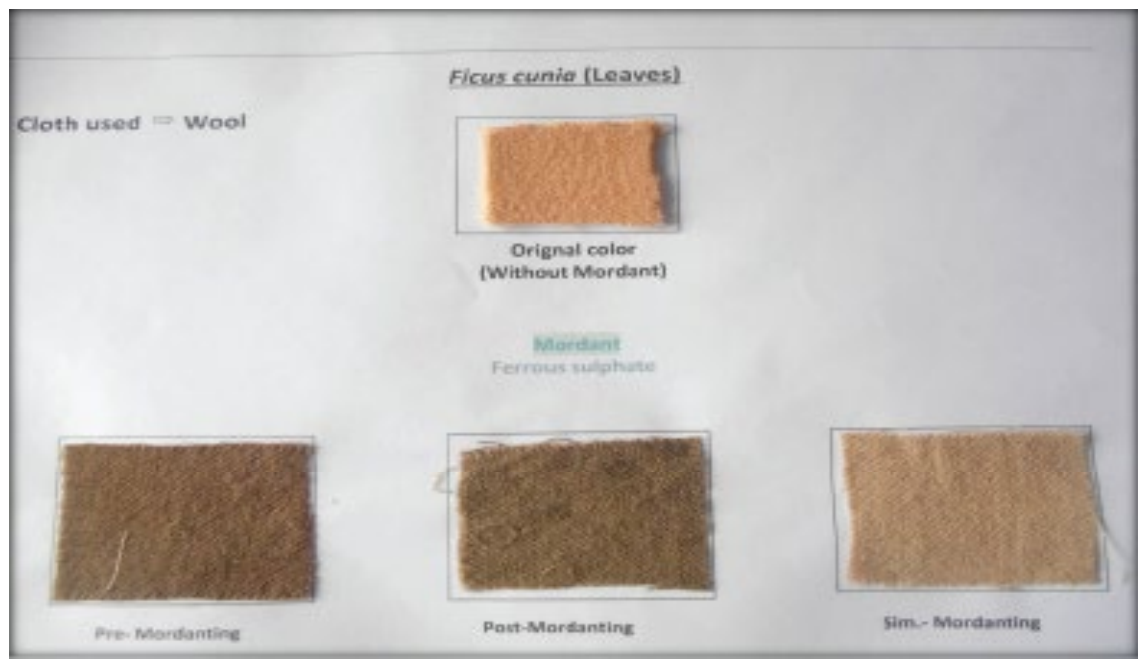

Photograph 7: Shows effects of various shades obtained from different mordants and mordanting methods.

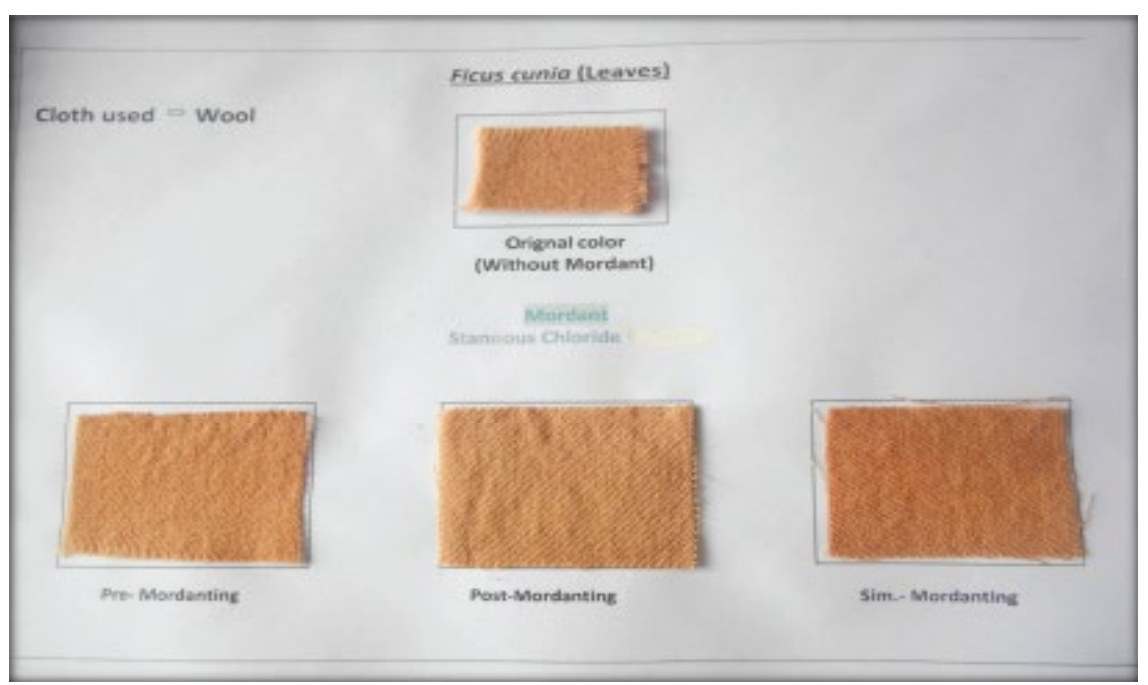

Photograph 8: Shows effects of various shades obtained from different mordants and mordanting methods.

toward the commercialization of natural dyeing to meet the increasing demand of natural dye.

\section{Acknowledgements}

Authors are highly thankful to Dr. R.V. Adveraker, Professor, Department of Fibre and Textile, ICT, Mumbai who let us completed this research work in his lab. Authors are also thankful to UGC, New Delhi for the financial support.

\section{References}

1. Berg CC (1989) Classification and distribution of Ficus. Experientia 45: 605611.

2. Singh HB, Parsad P, Rai LK (2002) Folk medicine plants in the Sikim Himalaya in India. Asian Folklore Studies 61: 295-310.

3. Siva R (2007) Status of natural dyes and dye yielding plants in India. Curr Sci 92: $916-925$

4. Purohit S, Mallick S, Nayak A, Das NB, Nanda B, et al. (2007) Developing multiple natural dyes from flower parts of Gulmohur. Curr Science 92: 168-682.

5. Shanker R, Vankar PS (2007) Dyeing wool and silk with Hibiscus mutabilis (Gulzuba). Dyes Pigments 74: 464-469.

6. Samanta AK, Agarwal P (2009) Application of Natural Dyes on Textiles. Ind J Fibre and Textile Res 34: 384-399.
7. Adeel S, Ali S, Bhatti IA, Zsila F (2009) Dyeing of Cotton Fabric using Pomegranate (Punica granatum) Aqueous Extract. Asian J Chem 21: 3493-3499.

8. Fossen T, Cabrita L, Andersen OM (1998) Colour and stability of pure anthocyanins influenced by $\mathrm{pH}$ including the alkaline region. Food Chem 63: 435-440.

9. Calnan CD (1976) Quinazoline Yellow SS in cosmetics. Contact Dermatitis 2 160-166.

10. Gao L, Qian X (2002) Synthesis and photosensitizing properties of fluoroalkoxy phthalocyanine metal complexes. J Fluor Chem 113: 161-165.

11. Sinha AK, Bihari B, Mandal BK, Chen L (1995) Nonlinear Optical Properties of a New Porphyrin-Containing Polymer. Macromolecules 28: 5681-5683.

12. Savarino P, Viscardi G, Quagliotto P, Montoneri BE (1999) Reactivity and effects of cyclodextrins in textile dyeing. Dyes and Pigments 42: 143-147.

13. Kongkachuichay P, Shitangkoon A, Chinwongamorn N (2002) Thermodynamics of adsorption of laccaic acid on silk. Dyes and Pigments 53: 179-185.

14. Evans E, McCarthy B (1998) Biodeterioration of natural fibres. JSDC 114: 114-116 